Article

\title{
Possibilities of Speciation in the Central Sandy Steppe, Woody Steppe Area of the Carpathian Basin through the Example of Festuca Taxa
}

\author{
Károly Penksza ${ }^{1}$, Attila Csík ${ }^{2}$, , Anna Fruzsina Filep ${ }^{3,4}$, Dénes Saláta ${ }^{1}$, Gergely Pápay ${ }^{1, *}$, \\ László Kovács ${ }^{1}$, Kristina Varga ${ }^{5}$ D, János Pauk ${ }^{6}$, Csaba Lantos ${ }^{6}$ and Zsuzsa Lisztes-Szabó ${ }^{3}$ \\ 1 Faculty of Agricultural and Environmental Sciences, Szent István University, Páter K u 1, \\ H-2100 Gödöllő, Hungary; penksza@gmail.com (K.P.); Salata.Denes@szie.hu (D.S.); \\ Kovacs.Laszlo.gmbt@szie.hu (L.K.) \\ 2 Institute for Nuclear Research, Bem tér 18/c, H-4026 Debrecen, Hungary; csik.attila@atomki.hu \\ 3 Isotope Climatology and Environmental Research Centre, Institute for Nuclear Research, Bem tér 18/c, \\ H-4026 Debrecen, Hungary; filepanna@atomki.hu (A.F.F.); lisztes-szabo.zsuzsanna@atomki.hu (Z.L.-S.) \\ 4 Pál Juhász-Nagy Doctoral School of Biology and Environmental Sciences, University of Debrecen, \\ Egyetem tér 1, H-4032 Debrecen, Hungary \\ 5 Institutes for Agricultural Research and Educational Farm, Research Institute, University of Debrecen, \\ Kisújszállási u. 16, H-5300 Karcag, Hungary; vargakrisztina@agr.unideb.hu \\ 6 Cereal Research Non-Profit Ltd., P.O. Box 391, H-6701 Szeged, Hungary; janos.pauk@gabonakutato.hu (J.P.); \\ csaba.lantos@gabonakutato.hu (C.L.) \\ * Correspondence: geri.papay@gmail.com
}

Received: 29 October 2020; Accepted: 9 December 2020; Published: 14 December 2020

\begin{abstract}
Research Highlights: We examined the vegetation appearing in forest-steppes in the Pannon region. In the present survey taxonomical relations of the dominant Festuca species were examined. Background and Objectives: After deforestation and shrubcutting bare soil patches exposed to anthropogenous effects provided an opportunity for new vegetation to form. Materials and Methods: Inflorescence parameters and micromorphological characters of the leaves were examined in a new taxon and compared with two, presumably closely related, species of the genus Festuca L. Festuca tomanii Korneck \& T.Gregor, with silvery leaf surface, Festuca vaginata W. K. and Festuca pseudovaginata Penksza were compared based on 24 traits of the inflorescence and their leaf anatomy studied on leaf cross-sections. Moreover, leaf micromorphological features were compared using a stereomicroscope, a scanning electron microscope completed with Energy Dispersive X-Ray Spectroscopy measurements and phytolith analysis method to establish the taxonomic applications of the micromorphological characters of the epidermis. Results: The awns of the lemma of Festuca tomanii were shown to be longer than those of the two other species. Festuca vaginata and Festuca pseudovaginata specimen showed low variability in inflorescence parameters but inflorescence characters were not uniform because the panicle of Festuca tomanii individuals was found to be bigger in the northern part than the panicles originating from the southern part of the sampled area. The phytolith assemblages of the Festuca pseudovaginata and Festuca tomanii differ from the Festuca vaginata in the abundance of ELONGATE SINUATE phytolith morphotype. Conclusions: we confirmed the appearance of $F$. vaginata in natural grasslands and discovered new occurrences of $F$. pseudovaginata and $F$. tomanii. F. pseudovaginata inhabits only the Pannon region, we found endemic and natural stands of it, but in its secondary habitats it was confirmed as a completely new species. Furthermore, taxa of disturbed vegetations are currently being examined. These habitats are potential hotspots of speciation.
\end{abstract}

Keywords: sandy grasslands; Danube-Tisza Interfluve; morphotaxonomy 


\section{Introduction}

These Festuca taxa from the Carpathian Basin which have bowed narrow leaves were mentioned by several authors as part of Festuca ovina agg. [1-14]. The study in [15] arrived at the same conclusion. Those species which have continuous sclerenchyma are classified into the eu-ovina aggregate. These taxa can be identified easily based on their characteristic tissue structure and molecular genetic analyses [16-27].

The study in [28] separated a new series within the Festuca genus. One example is the psammophila series, which includes F. polesica Zapal, F. vaginata W. K., F. psammophila Host., F. pallens. Subsequently, [26] supplemented the series with F. pseudovaginata Penksza and F. glaucina Stohr.

In association with these groups was the taxon in question: F. dominii Krajina. According to [29], F. dominii was the dominant species in acidic sandy grasslands. F. dominii was described for the first time as a species by [30] and its taxonomical status was defined differently by various authors. According to [12], it was a varietas named F. vaginata var. dominii, although, [31] and [13] referred to this species as F. vaginata subsp. dominii, as did [2] and [11] also. Some databases do not emphasize the taxonomic importance of subspecies and $F$. dominii is considered to be a subspecies of either F. vaginata or F. psammophila as a synonym [32]. The taxonomic position of F. dominii Krajina was not clear, $[13,14,24,25]$ named the taxon F. vaginata subsp. dominii (Krajina) P. Šmarda and [25] clarified the taxonomic status of the species and concluded that it was a subspecies of F. psammophila (Čelak.) Fritsch (which currently occurrs only in pine forests in Northern Europe [17]). Therefore, the accepted name of the species is F. psammophila subsp. dominii (Krajina) P. Šmarda. [33,34] examined and collected individuals belonging to $F$. vaginata in Hungarian sample sites. Based on the results, the F. vaginata taxon was found typically without awn. Moreover, we collected short or longer awn from the tip of the lemma, which had short awn under the tip of the lemma.

The study in [28] also distinguished the F. trachyphylla series, which included three species: F. trachyphylla (Hack.) Krajina, F. macutrensis Zapalowicz, F. duvalii (St-Yves) Storh. According to [35] F. brevipila (Tracey) was mistaken for decades about F. longifolia Thuill. In the present study it is already apparent that F. trachyphylla (Hack.) Kraj. and Festuca brevipila, although synonymous with F. trachyphylla, are present mainly due to coenological work conducted in this period [27,36-38]. According to [26], the F. trachyphylla taxon was validly referred to as F. brevipila. The species predominates in the pine forests of northern Europe, in sandy areas [24,25], although according to [35] it also occurs in many places in the United Kingdom. According to [39], it could be common in other sandy habitats (dunes, xerothermal sand grasslands) since it is a highly variable species with a wide ecological spectrum due to its morphological characteristics. The taxon was reported to be present in a variety of habitats but primarily in lime-poor habitats. It is common in several sources in the Koelerio-Corynephoretea association [40-42] and the Spergulo-vernalis Corynephoretea [43]. [44] Koelerion-Glaucae, [45] Sileno otitis-Festucetum, [46] described significant populations in the Potentillo-Stipetum association. The study in [47] also described it as an associative species and [48] as a character of the Violo pseudogracilis-Koelerietum splendentis ass. nov. hoc loco association. The study in [49] examined F. ovina agg. morphological features, including the F. brevipila taxon. The taxon has been extensively studied and researched. In [27] the ISSR (Inter-Simple Sequence Repeat) fingerprint analysis proved to be a useful aid in distinguishing the safe F. brevipila from other closely related species. The present study aims to describe the identifying characters. Besides the leaf schlerechyma and inflorescence features, the micromorphological characters of leaf epidermis are useful tools to identify species, especially in the family Poaceae [50-54]. Grasses deposit hydrated $\mathrm{SiO}_{2}$ in epidermal cell walls and cells (silica bodies, phytoliths), which are genetically controlled and have taxonomical relevance [55-62]. Micromorphology, as an application, has a high priority for taxonomic studies of genus Festuca [63-65].

The study in [66] described a new Festuca taxa: Festuca tomanii Korneck \& T.Gregor sp. nov., a fescue of sand dunes of the valleys of the northern Upper rhine, the middle main and the Bohemian Elbe. Blue green tetraploid fescues grow on base rich sands. Previously addressed as F. duvalii, they were described as F. tomanii. F. tomanii differs from F. duvalii by parchment-like sheaths of the basal 
leaves, of which a \pm continuous sclerenchyma (F. duvalii: sclerenchyma mainly in three bundles). Festuca tomanii, a new taxon for Hungarian flora was found in the area of Újpesti Homoktövis TT [67].

Goals and hypotheses: How do the taxa found or newly discovered in identical environmental conditions differ from one another? Are there any relevant morphotaxonomical parameters the taxa can be distinguished in the field work based on? Is there a possibility for new vegetation units and species on new surfaces formed by human interventions to form, or would natural vegetation and its main species appear?

\section{Materials and Methods}

The specimens of the three Festuca taxa were transplanted in the Experimental Garden of the Genetics Institute (Szent István University, Gödöllő, Hungary) in 2018 and 2019. Inflorescences were collected from individuals grown under the same conditions for assays, leaf tissue and phytolith analysis by the dry ashing technique.

\subsection{Inflorescence Measurements}

For the inflorescence parameter analyses, 5-5 flowering stems were collected from each Festuca specimen and their parameters were measured. The origin of the individuals was as follows.

Festuca vaginata individuals. Hungary, Little Hungarian Plain (Győrszentiván (47.7167859, 17.7378554)), Danube-Tisza Interfluve (Tahitótfalu (47.799908, 19.042440)), Kisoroszi (47.808996, 18.999420), Homoktövis TT (47.602555, 19.097076), Tatárszentgyörgy (47.062065, 19.350956), Imrehegy, Inner Somogy (Böhönye $(46.416657,17.469680))$, South Slovakia (near Ćenkov $(47.767248,18.527781)$ ), Serbia (Deliblato Sands $(44.955270,21.113502))$, Romania (Balta Verde $(44.328763,22.620251))$. A total of 24 individuals' morphology parameters were measured as follows: 1. length of the generative stem; 2. length of inflorescence; 3 . length of the longest branch on the 1st node; 4 . length of the longest branch on the 2nd node; 5 . length of the 4 th spikelet from the top of the branch (1); 6 . length of 4th spikelet from the top of inflorescence; 7. length of the 1st internode of the inflorescence. 7-15 (1): 4th spikelet from the top of the branch (2): 8. the floral number of spikelets, 9. length of upper glume, 10. length of lower glume, 11 . length of the 2nd flower's lemma, 12. length of the 2nd flower's awn, 13. hair of spikelet, 14. length of the 1st flower's lemma, 15. length of the 1st flower's awn, 17-24. 4th spikelet from the top of inflorescence: 17: floral number of the spikelet, 18. length of upper glume, 19. length of lower glume, 20. length of the 2nd flower's lemma, 21. length of the 2nd flower's awn, 22. hair of spikelet 23. length of the 1st flower's lemma, 24. length of the 1st flower's awn.

Festuca pseudovaginata individuals. Hungary, Danube-Tisza Interfluve (Kisoroszi, Homoktövis TT, Szigetszentmiklós (47.650506, 19.091616), Kunpeszér, Kunadacs $(47.116246,19.259816))$. A total of 17 individuals' morphology parameters were measured.

Festuca tomanii individuals. Hungary, Danube-Tisza Interfluve (Kisoroszi, Homoktövis TT, Szigetszentmiklós, Tatárszentgyörgy). A total of 20 individuals' parameters were measured.

The analyzed parameters were as follows according to $[33,68]$.

We analyzed 24 traits for each inflorescence altogether with ordination methods and for representation discriminant analysis was used. Data were analyzed using the PAleontological STatictics Version 3.06 (PAST [69]) statistical software package. Data evaluation was performed using both classical cluster (UPGMA-Unweighted pair-group average) and ordination analysis (PCA-Principal components analysis) [70] using the former Euclidean mean distance; in the latter case, biplot and minimum spanning tree settings were used for better interpretation. For this reason, we made radar chart diagrams with polar grid typesetting of the most highlighted parameters.

\subsection{Leaf Micromorphological Investigations}

A total of 10 leaves of each of the three taxa were prepared for micromorphological investigations. The leaves were cleaned carefully before the examination to keep the prickles and hairs intact. Cross-sections of the leaf blades were made between the lower third and the middle of the leaves. 
The air-dry cross-sections were fixed on double-sided tape mounted on an aluminum stub and were coated with gold (BIO-RAD E5000C Sputter Coater). A short section (a few mm) was cut from the same position of the leaves and fixed on an aluminum stub as described above, making the abaxial surface visible. The images were taken with a Hitachi S4300-CFE scanning electron microscope (SEM). Photos of the abaxial epidermis - and spikelets—were also taken under a Zeiss Stereo Discovery.v20 stereomicroscope. Three individual analysis measurements of the abaxial epidermis of the leaves per species were conducted using the SEM with energy dispersive X-ray fluorescence (EDX), operating at $15 \mathrm{kV}$ with a detection threshold of 0.1 atom \%.

Leaf blades from ten lateral shoots of the same species were collected and were treated as one single sample. Phytolith extraction was accomplished through the dry-ashing technique based on the methodological guidelines published earlier by [71-73]. The ashes were mixed thoroughly and mounted on light microscope slides in immersion oil and observed under an Alpha Euromex CMEX-5 polarized light microscope at a magnification of 400x. The phytolith samples were stored in Eppendorf tubes in the Phytolith Collection of Isotope Climatology and Environmental Research Centre (ICER) with a laboratory code of 115.2108.1-3.

A total of 3000 pieces of identifiable plant opal particles-phytoliths-per species were counted in adjacent but not in overlapping lines across the coverslip (with $22 \mathrm{~mm}$ length). The denomination of individual morphotypes was accomplished according to the International Code for Phytolith Nomenclature 2.0 (ICPN 2.0; [74]). Phytolith analysis was focused on the most abundant morphotypes, on grass silica short-cell phytoliths (GSSCP), long epidermal cells (ELONGATE) and long unicellular hairs or short prickles (hereunder trichomes with a common name) as these are relevant in the taxonomic aspect and can help to reveal the reason for the silver color of $F$. tomanii leaves. Hierarchical cluster analysis was undertaken (using PAST, [69]) on the phytolith frequency data.

\subsection{Flow Cytometric Analyses}

The ploidy level of the Festuca spp. was determined by flow cytometric analyses using a flow cytometer (CytoFLEX Flow Cytometer). The experiments were repeated at least three times.

The leaf samples (100 mg/plant) were collected from young leaves of plants. The samples were crashed in Eppendorf tubes containing $1 \mathrm{ml}$ Galbraith puffer and two stainless steel beads using TissueLyser II at $20 \mathrm{~Hz}$ for $3 \mathrm{~min}$ [75] The suspensions were purified using $20 \mu \mathrm{m}$ sieves and $10 \mu \mathrm{L}$ RNase solution was added to each sample for $60 \mathrm{~min}$ to eliminate the RNA content. DNA content was painted with $40 \mu \mathrm{L}$ Propidium iodide (PI) solution $(1 \mathrm{mg} / \mathrm{mL}$ ) for $30 \mathrm{~min}$, and the samples were measured by the flow cytometer. After the flow cytometric analyses, the ploidy levels of samples were determined based on histograms.

\section{Results}

\subsection{Characters of Inflorescences}

The spikelets of $F$. vaginata consisted of 4-5 flowers and those of F. tomanii comprised 5-6 flowers at (Figures 1 and 2). Most of the spikelets of $F$. pseudovaginata included five flowers with an infertile flower at the tip of the spikelets. Awns of the F. vaginata lemma were between $0.2-0.4 \mathrm{~mm}$ and those of F. pseudovaginata between 1-1.5 mm, and the awns of F. tomanii were longer than $2 \mathrm{~mm}$.

Differences were found between the taxa based on the inflorescence data. The most important distinctive feature was the shorter inflorescence $(13.47 \pm 2.64 \mathrm{~cm})$, the length of the longest branch on the 1st node $(5.28 \pm 1.78 \mathrm{~cm})$, which were longer and larger (F. pseudovaginata: $6.97 \pm 0.96 \mathrm{~cm}, F$. tomanii: $8.83 \pm 1.78 \mathrm{~cm}$ ). In addition, the significantly shorter and smaller parameters measured included the length of the 4th spikelet from the top of the branch (F. vaginata: $6.20 \pm 0.85 \mathrm{~cm}$. F. pseudovaginata: $7.91 \pm 0.52 \mathrm{~cm}, F$. tomanii: $8.46 \pm 0.61 \mathrm{~cm}$ ), the length of the 4th spikelet from the top of the inflorescence (F. vaginata: $6.02 \pm 0.77 \mathrm{~cm}$. F. pseudovaginata: $8.69 \pm 0.61 \mathrm{~cm}, F$. tomanii: $8.49 \pm 0.90 \mathrm{~cm}$ ), the length of the upper glume (19: F. vaginata: $6.02 \pm 0.77,3.06 \pm 0.55 \mathrm{~mm}$, F. pseudovaginata: $8.69 \pm 0.61,3.70 \pm 0.56 \mathrm{~mm}$, 
F. tomanii: $8.49 \pm 0.90,3.80 \pm 0.37 \mathrm{~mm})$, the length of the lower glume (20 F. vaginata: $2.10 \pm 0.22$, $2.31 \pm 0.42 \mathrm{~mm}$, F. pseudovaginata: $2.79 \pm 0.19,2.58 \pm 0.41 \mathrm{~mm}$, F. tomanii: $2.48 \pm 0.23,2.69 \pm 0.33 \mathrm{~mm})$, the length of 1st flower's awn (24: F. vaginata: $0.18 \pm 0.16,0.12 \pm 0.11 \mathrm{~mm}$, F. pseudovaginata: $1.64 \pm 0.20$, $1.51 \pm 0.19 \mathrm{~mm}$, F. tomanii: $2.13 \pm 0.30,1.93 \pm 0.34 \mathrm{~mm})$ and the length of 2nd flower's awn (21: F. vaginata: $0.17 \pm 0.08,0.21 \pm 0.14 \mathrm{~mm}$, F. pseudovaginata: $1.34 \pm 0.16,1.47 \pm 0.20 \mathrm{~mm}$, F. tomanii: $2.15 \pm 0.26,2.21 \pm 0.36 \mathrm{~mm})$.
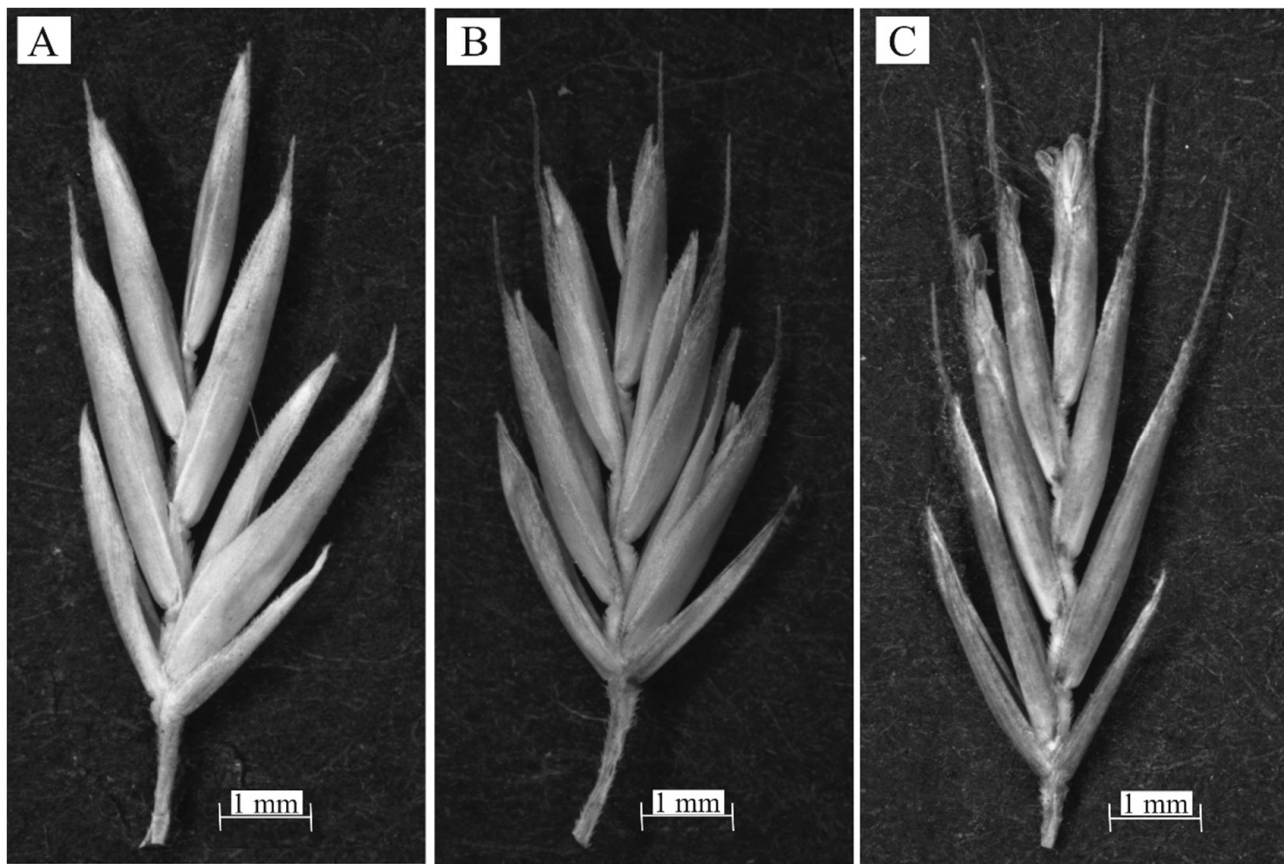

Figure 1. Typical spikelets of Festuca vaginata W. K. (A), Festuca pseudovaginata Penksza (B) and Festuca tomanii Korneck \& T.Gregor (C).
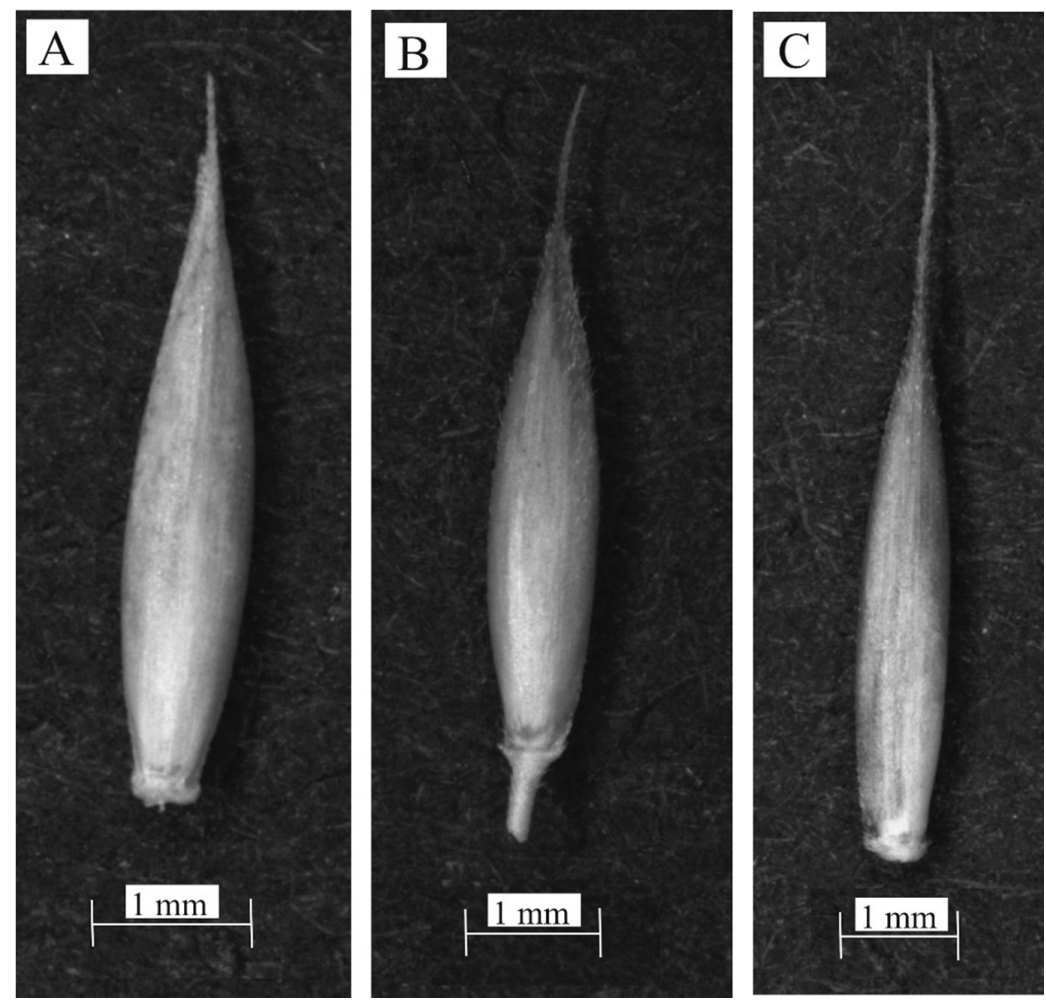

Figure 2. Tipycal lemma of F. vaginata (A), F. pseudovaginata (B) and F. tomanii (C). 
The length of the generative stem showed no difference between the three taxa, and was omitted when analyzing the data. The hair of the spikelet was also not informative

The minimum spanning tree (Figure 3) and biplot options of the ordination (PCA) analysis highlighted the most responsible morphological features for species differences (Figure 4). Festuca vaginata separates from the other two species at a great degree. Within $F$. vaginata, there are two more groups, based on geographical location. Inflorescneces of samples originating from the southern part of the area (Balta Verde, Deliblát, Imrehegy, Tatárszentgyörgy) are relatively larger, which make them separate. The separation of $F$. vaginata was represented by the following stamps: the other two species had a much longer inflorescence $(13.5 \mathrm{~cm})$, the longest branch on the first node and the short awn of lemma

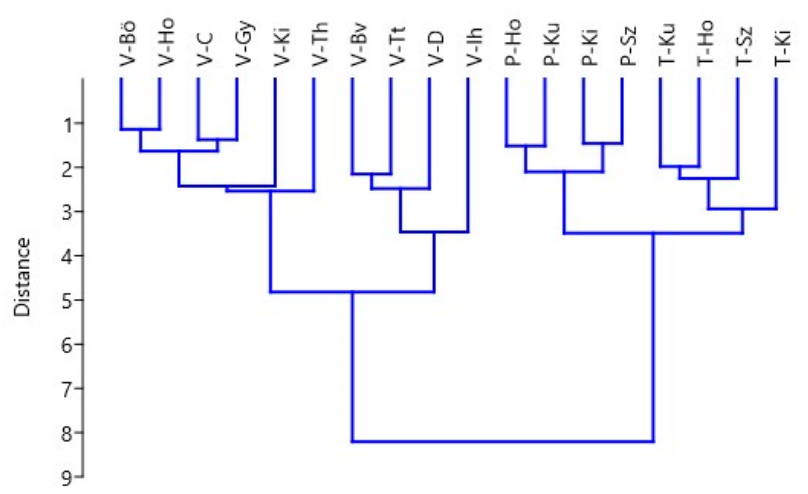

Figure 3. Classification inflorescence parameters of investigated Festuca taxa (V: F. vaginata, P: F. pseudovaginata, H: F. tomanii, Bö: Böhönye, Ho: Momoktövis TT, C: Ćenkov, Gy: Győrszentiván, Ki: Kisoroszi, Th: Tahitótfalu, Vv: Balta Verde, Tt: Tatárszentgyörgy, D. Deliblato, Ih: Imrehegy, Ku: Kunpeszér, Kunadacs, Sz: Szigetszentmiklós).

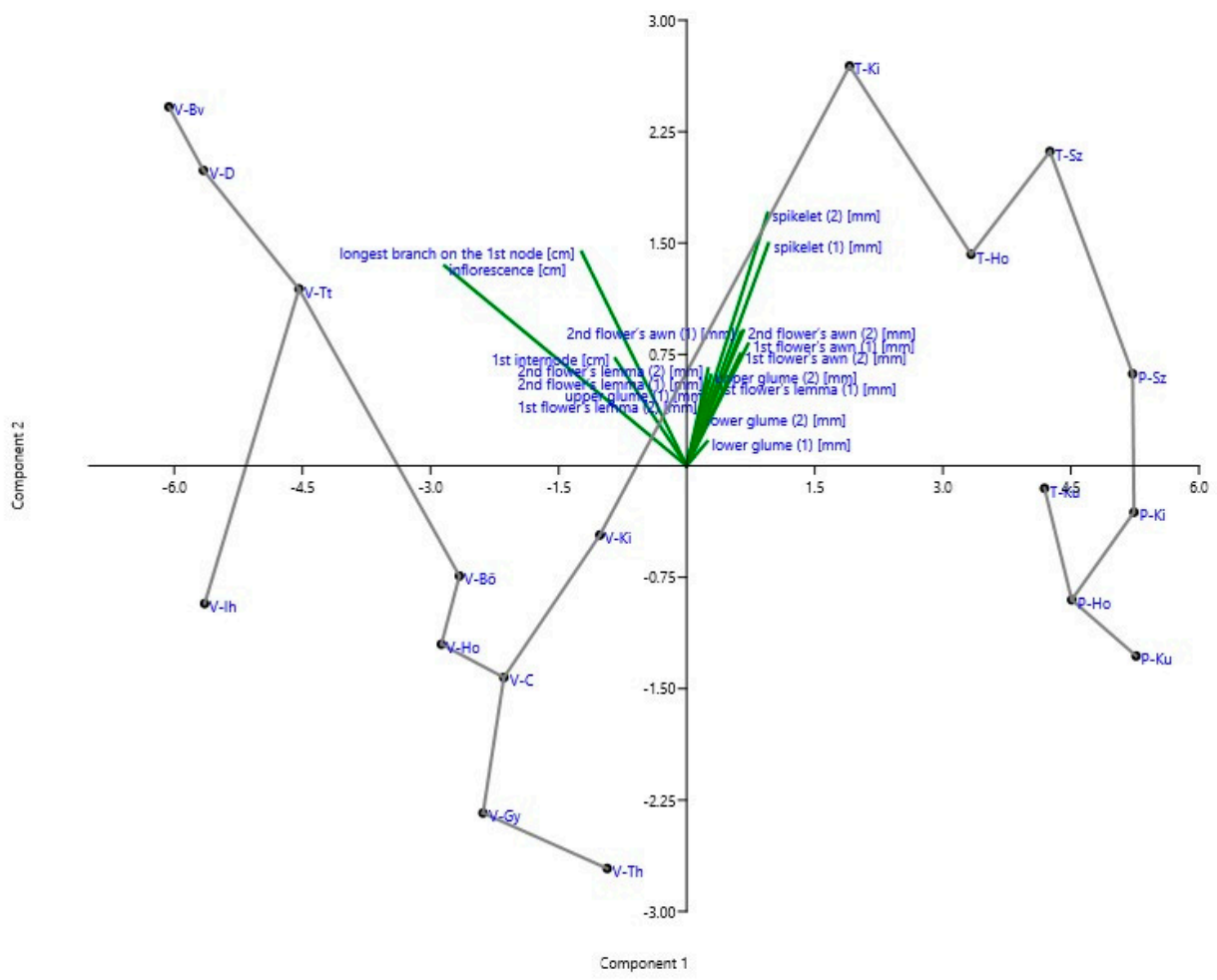

Figure 4. Classification inflorescence parameters of investigated Festuca taxa (V: F. vaginata, P: F. pseudovaginata, H: F. tomanii, Bö: Böhönye, Ho: Momoktövis TT, C: Ćenkov, Gy: Győrszentiván, Ki: Kisoroszi, Th: Tahitótfalu, Vv: Balta Verde, Tt: Tatárszentgyörgy, D. Deliblato, Ih: Imrehegy, Ku: Kunpeszér, Kunadacs, Sz: Szigetszentmiklós). 
Figure 4 also highlights the morphological parameters which made F. pseudovaginata and F. tomanii different. The spikelet was also a distinctive feature of $F$. vaginata and $F$. pseudovaginata of the fourth spikelet from the top of the branch, as the fourth spikelet from the top of the branch. In the case of F. tomanii, this length was reversed and the fourth spikelet from the top of the branch was shorter. In these cases, similarly to F. vaginata, there was a difference according to their geographical distribution with the size of the specimens (Ku: Kunpeszér, Kunadacs) from the southern part of the studied areas and the south part (central Kiskunság) being smaller (north part: $8.18 \pm 0.55 \mathrm{~mm}$, south part: $7.56 \pm 0.14 \mathrm{~mm}$ ).

Differences between F. pseudovaginata and F. tomanii: length of the 2nd flower's awn, length of the 2nd flower's lemma, the length of the lemma awn, length of upper glume, length of 1st flower's lemma, length of 1st flower's awn.

A radar chart with polar grid type options illustrate differences in the taxa studied. The four morphological parameters were highlighted (Figure 5). The length of inflorescence (Figure 5A), which shows that the length values of $F$. vaginata were almost twice as long as the values of $F$. pseudovaginata inflorescence and the $F$. tomanii inflorescence was between the two. The difference in the length of the fourth spikelet from the top of the branch (Figure 5B) was barely significant but here the species differences could be detected, with the highest values appearing in F. pseudovaginata and the lowest in F. vaginata. The most striking differences were the length of the second flower's awn (Figure 5C). The awn lemma in $F$. vaginata was absent or very short, the longest in the F. tomanii taxon. The length of the upper glume (Figure 5D) had a smaller difference in size, with the highest values given by F. pseudovaginata and the smallest length values given by $F$. vaginata.
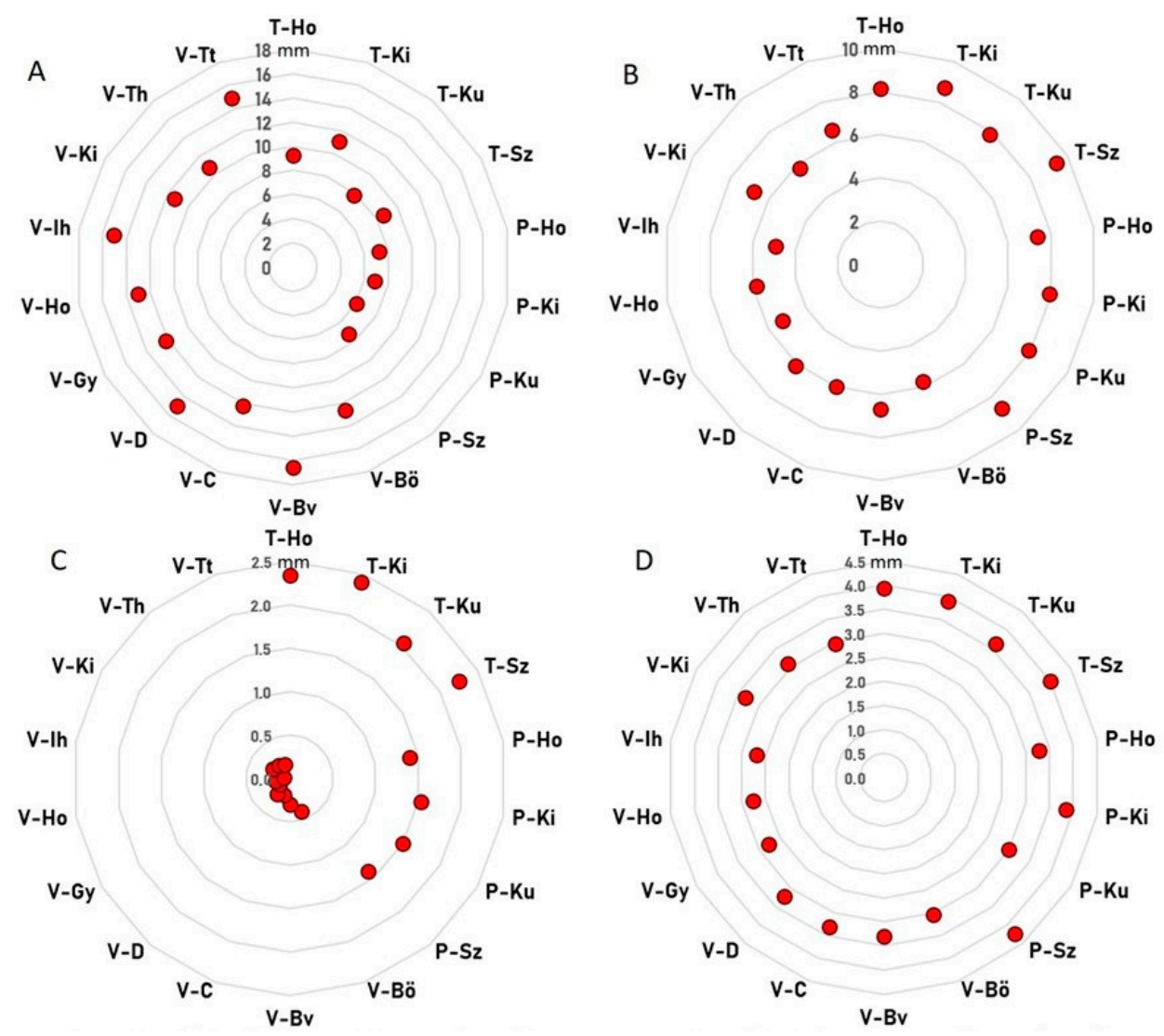

Figure 5. Radar chart with polar grid type options of some morphologycal marcs of investigated Festuca taxa (A: the length of inflorescence, B: length of the 4th spikelet from the top of branch, C: the length of the 2nd flower's awn, D: length of upper glume, V: F. vaginata, P: F. pseudovaginata, H: F. tomanii, Bö: Böhönye, Ho: Momoktövis TT, C: Ćenkov, Gy: Győrszentiván, Ki: Kisoroszi, Th: Tahitótfalu, Vv: Balta Verde, Tt: Tatárszentgyörgy, D. Deliblato, Ih: Imrehegy, Ku: Kunpeszér, Kunadacs, Sz: Szigetszentmiklós). 


\subsection{Leaf Micromorphology}

\subsubsection{Anatomy}

Leaf anatomy of each of the three taxa was characterized by the number of vascular bundles of 7-9 (Figure 6). The adaxial leaf surface was covered by trichomes. The position of the sclerenchyma band was annular at the three species. The only difference we found was that one to three indenting epidermal cells interrupted the sclerenchyma ring in the leaf of $F$. tomanii at both sides near the middle vascular bundle.
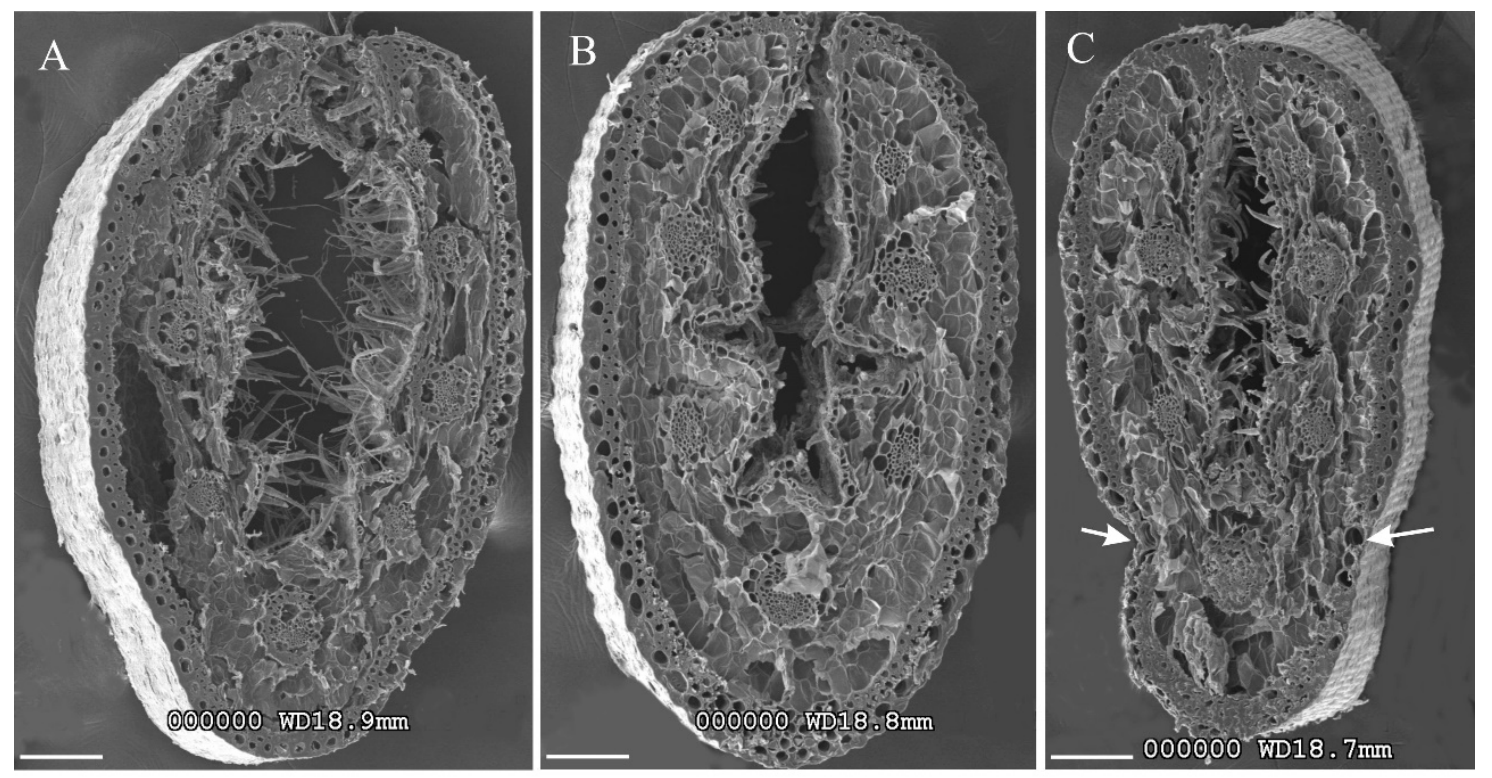

Figure 6. SEM pictures of the typical leaf cross sections. (A) F. vaginata (B) F. pseudovaginata (C) F. tomanii. White arrows show the interruptions of the continuous sclerenchyma ring at F. tomanii. The line represents $100 \mu \mathrm{m}$.

\subsubsection{Phytoliths of the Leaves}

Approximately 500-1000 phytolith microphotos were taken of every species with a total of 9000 (3000 per species) classified silica bodies in them (Figure 7). Several small pieces of silicified tissue were found because the cells adhered to each other sufficiently during the extraction process. Five phytolith morphotypes were counted including (following the ICPN 2.0) grass silica short-cell phytoliths (GSSCP, RONDELS), epidermal long cells with different ornaments (ELONGATE ENTIRE, ELONGATE SINUATE, ELONGATE DENTATE) and silicified trichomes (ACUTE BULBOSUS) (Table 1). There were no significant differences found in the frequency of the GSSCPs and trichomes between the species. The frequency of the ELONGATE cells was bigger at $F$. pseudovaginata and $F$. tomanii than at $F$. vaginata but the differences are not considerable. However, the distribution of the ELONGATE morphotypes represented some differences. Most of the ELONGATE phytoliths of $F$. vaginata were ELONGATE ENTIRE morphotype (81.2\%) but most of the ELONGATE phytoliths of $F$. pseudovaginata and $F$. tomanii belonged to the ELONGATE SINUATE morphotype (Table 1). As a result of the hierarchical cluster analysis (Figure 8), F. pseudovaginata and F. tomanii were close to each other based on their phytolith assemblages. 

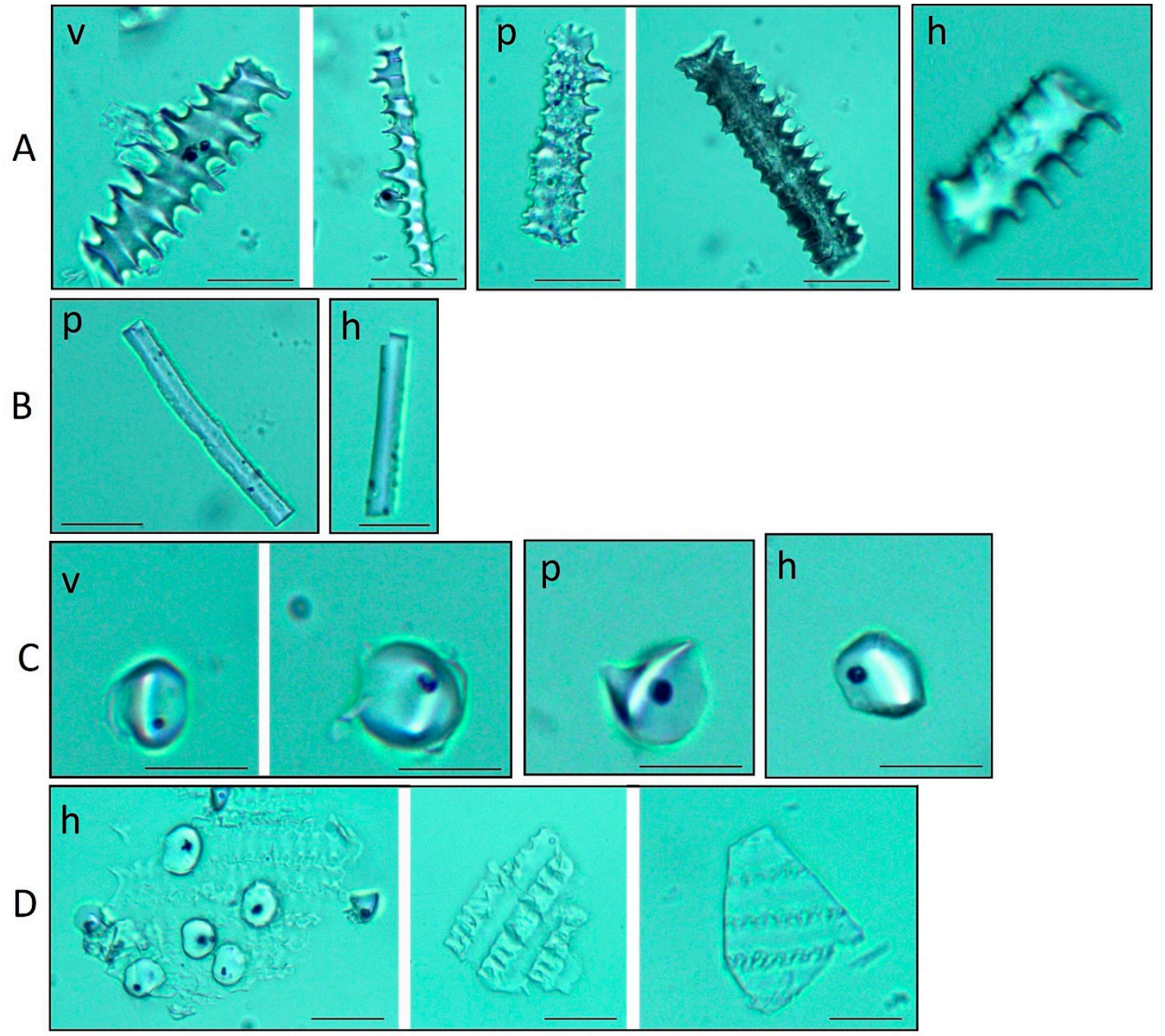

Figure 7. Light microscopic pictures of phytoliths. (A) ELONGATE DENTATE (B) ELONGATE ENTIRE (A,B) Silicified epidermal long cells) (C) RONDEL (silicified epidermal short cell), (D) epidermal tissue fragments with short cells and ELONGATE SINUATE phytoliths in them. (v) F. vaginata (p) F. pseudovaginata (h) F. tomanii. The line represents $20 \mu \mathrm{m}$.

Table 1. Frequency (\%) of phytolith morphotypes in the leaves of Festuca species (sum of all the phytoliths is $100 \%$ ). Frequency of the ELONGATE morphotypes means the percentage of the amount of ELONGATE cells (sum of the ELONGATE cells is 100\%). GSSCP = grass silica short-cell phytolith.

\begin{tabular}{ccccccc}
\hline & $\begin{array}{c}\text { GSSCP } \\
\mathbf{( \% )}\end{array}$ & $\begin{array}{c}\text { Elongate } \\
\text { Entire } \\
\mathbf{( \% )}\end{array}$ & $\begin{array}{c}\text { Elongate } \\
\text { Sinuate } \\
\mathbf{( \% )}\end{array}$ & $\begin{array}{c}\text { Elongate } \\
\text { Dentate } \\
\mathbf{( \% )}\end{array}$ & $\begin{array}{c}\text { Elongate } \\
\mathbf{( \% )}\end{array}$ & $\begin{array}{c}\text { Acute } \\
\text { Bulbosus } \\
\mathbf{( \% )}\end{array}$ \\
\hline F. vaginata & 88.3 & 81.2 & 11.9 & 6.9 & 10.7 & 1.0 \\
F. pseudovaginata & 81.6 & 39.2 & 52.5 & 8.3 & 17.7 & 0.7 \\
F. tomanii & 84.5 & 39.6 & 51.4 & 9.0 & 14.5 & 1.0 \\
\hline
\end{tabular}




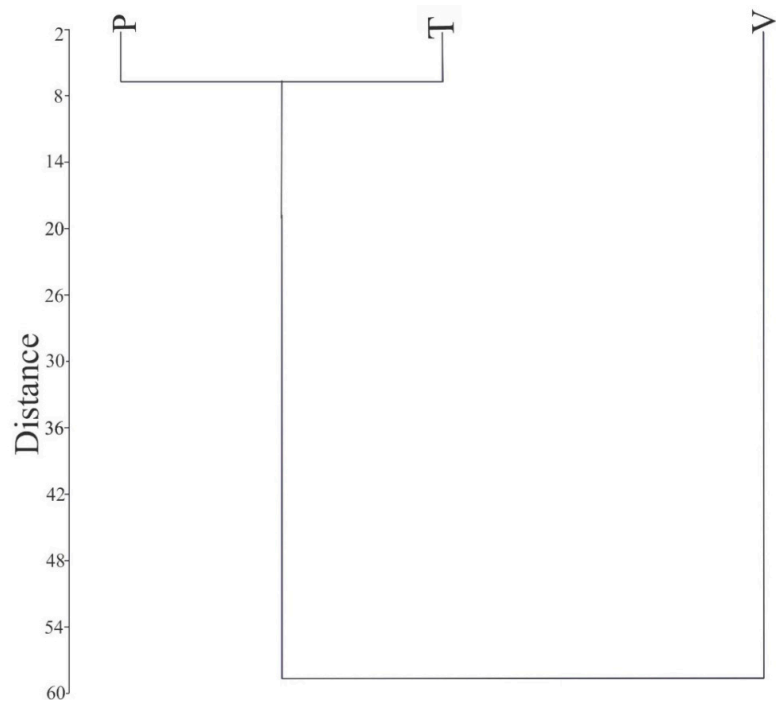

Figure 8. Hierarchical cluster dendrogram showing Festuca species grouping based on their phytolith assemblages (single linkage, Euclidean distance). V: F. vaginata, P: F. pseudovaginata, T: F. tomanii.

\subsubsection{Micromorphological Characters of the Epidermis}

Because F. tomanii leaves have silver coloration that can help to identify this taxon, differences in the micromorphological features of the abaxial leaf epidermis were expected to be found. The abaxial, dorsal epidermis of the leaves of $F$. vaginata was smooth, with short cells and the stomata submerged (Figure 9). Only a few short trichomes $(20-30 \mu \mathrm{m})$ were found in the abaxial epidermis of the F. pseudovaginata leaves, sparsely at the leaf margins. However, the abaxial epidermis of the F. tomanii leaves had longer trichomes (with 30-100 $\mu \mathrm{m}$ ) occurring more frequently (Figure 9).
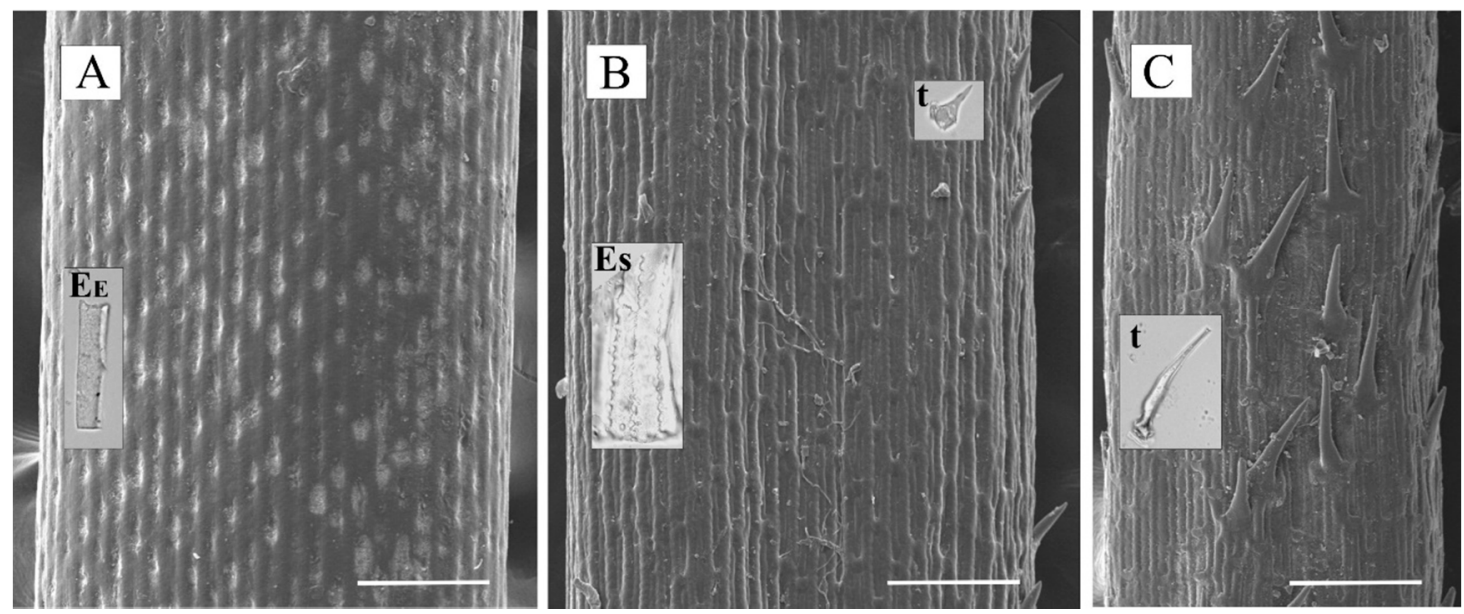

Figure 9. SEM pictures of the abaxial leaf surfaces: (A) F. vaginata (B) F. pseudovaginata (C) F. tomanii. Embedded figures are light microscopic pictures of phytoliths: EE ELONGATE ENTIRE phytoliths typical for F. vaginata, ES ELONGATE SINUATE phytoliths typical for F. pseudovaginata and F. tomanii, $\mathrm{t}$ trichomes typical for the abaxial surfaces of leaves at two latest species. The line represents $100 \mu \mathrm{m}$.

Moreover, silicified long cells were found in the abaxial surfaces of $F$. tomanii leaves under a stereomicroscope but there were no similar silicified cells in the epidermis of $F$. vaginata or F. pseudovaginata (Figure 10). EDX measurements supported the higher silicon content of $F$. tomanii leaves. The mean $\mathrm{Si}$ atom \% values of this leaf surface were the following: at $F$. vaginata 3.65 atom \%, F. pseudovaginata 3.50 atom \% and at F. tomanii 14.2 atom \%. 

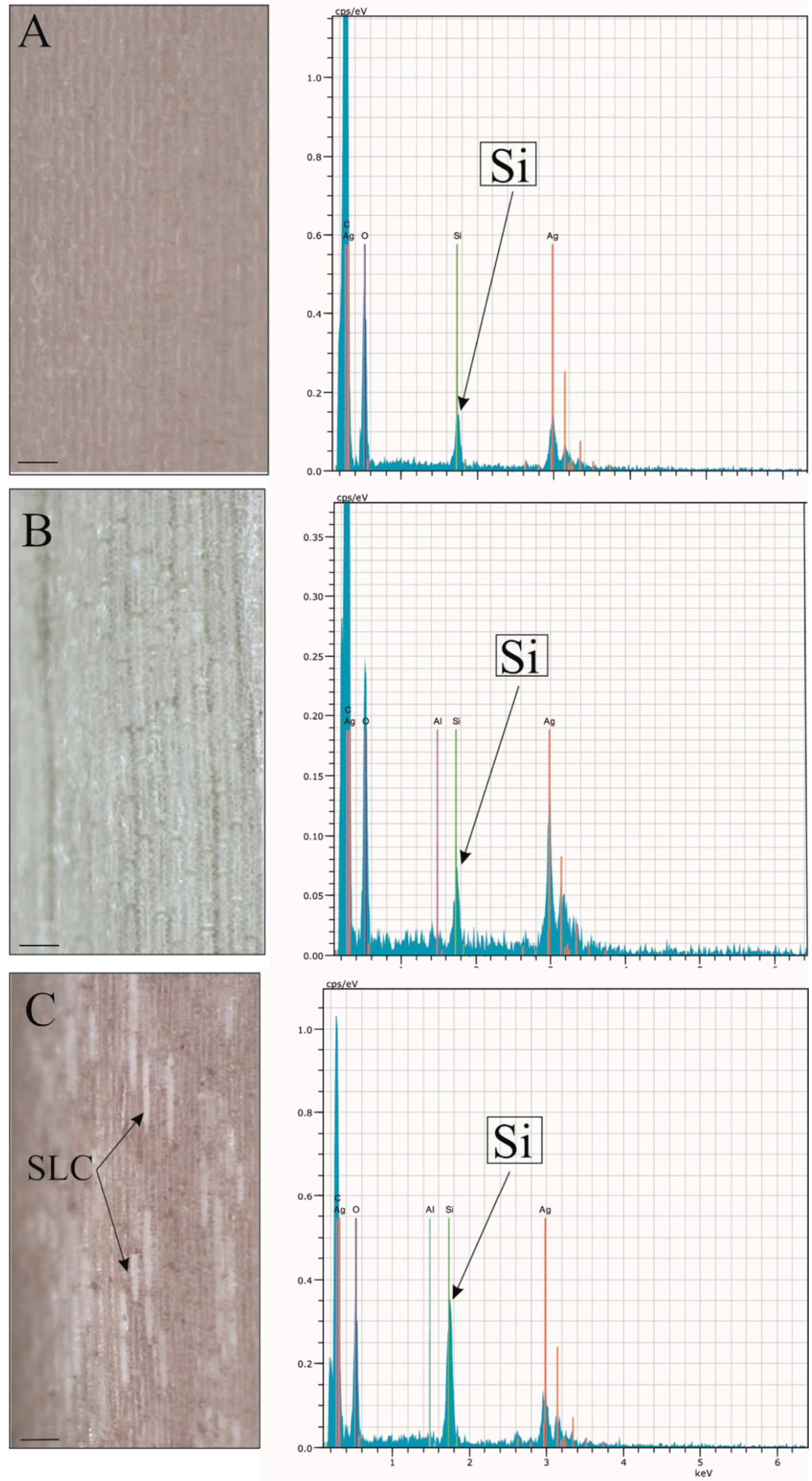

Figure 10. Stereomicroscopic pictures of the abaxial leaf surfaces: (A) F. vaginata (B) F. pseudovaginata (C) F. tomanii, with the EDX element spectrum diagrams near them. SLC: silicified long cells in the epidermis of F. tomanii. The line represents $50 \mu \mathrm{m}$. 


\subsection{Determination of Ploidy Level}

The ploidy levels of Festuca spp. were determined using flow cytometric analyses. The measurements revealed the differences of DNA content among the tested samples (Figure 11). The relative DNA content was two times higher in samples of Festuca pseudovaginata (Figure 11B) and Festuca tomanii (Figure 11C) than in the sample of the diploid Festuca vaginata species (Figure 11A).

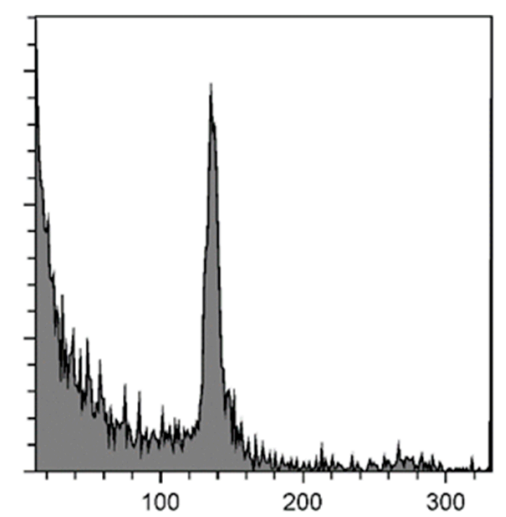

(A)

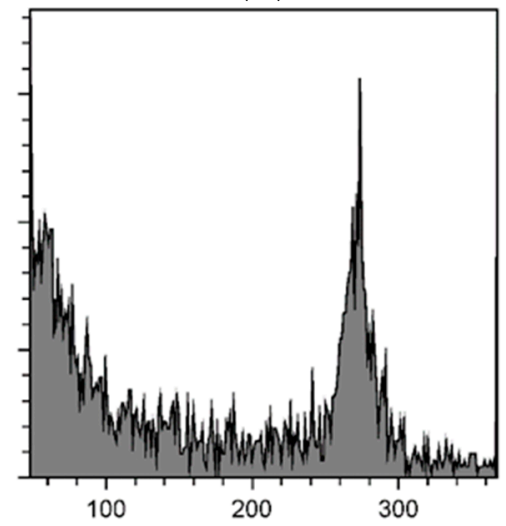

(B)

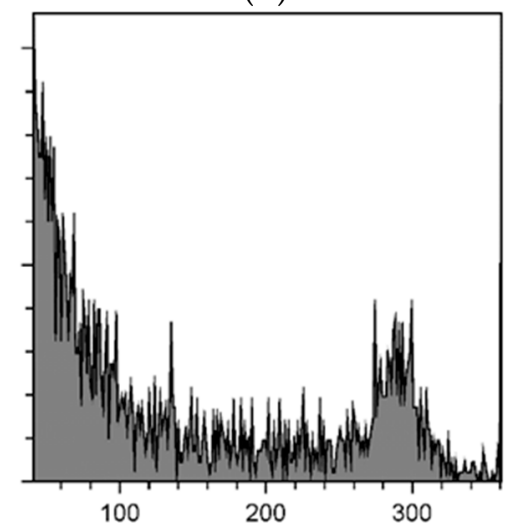

(C)

Figure 11. Flow cytometric analyses of Festuca spp.: histograms demonstrate the relative DNA content of (A) Festuca vaginata, (B) Festuca pseudovaginata and (C) Festuca tomanii.

\section{Discussion}

One of the most important identification keys to these Festuca taxa was the length of the awn of the lemma. Awns of $F$. vaginata were missing or very short $(0.2-0.4 \mathrm{~mm})$, confirming the findings of $[25,26]$ and [34]. Awn of the lemma of F. pseudovaginata is longer (1.2-1.8 mm) according to [76]. 
Awn of the lemma of F. tomanii is significantly longer than $2 \mathrm{~mm}$ [77], which was confirmed by the present study results.

Among the inflorescence parameters there were morphological markers that were not suitable for distinguishing the three species examined, such as the length of the generative stem, floral number of spikelet, length of upper glume and hairiness. Beyond these marks, F. vaginata was distinguished by the other parameters studied, including the longer inflorescence branch and the significantly longer lower inflorescence branch. The spikelet was the shortest of the three taxa examined. According to the spikelet, F. pseudovaginata and F. tomanii can be distinquished. The studies in $[78,79]$ highlighted this fact. According to $[78,79]$, samples must be taken from one particular point of the panicle. The present data confirmed $[78,79]$ finding that a spikelet at a given position should be examined. In the case of F. goals and no hypotheses, the fourth spikelet at the lower inflorescence branch was longer than the fourth spikelet at the apex of the inflorescence, which is also a good distinguishing morphological parameter of identification.

The distribution of the different phytolith morphotypes did not answer the question of what caused the silver coloration of the F. tomanii leaves. There were no more ELONGATE phytoliths or trichomes in the $F$. tomanii leaves than in the two other species but the phytolith analysis highlighted the differences between the micromorphological features of the abaxial epidermis surfaces of the studied Festuca leaves, namely that most of the ELONGATE phytoliths of $F$. vaginata were the ELONGATE ENTIRE morphotype but most of the ELONGATE phytoliths of $F$. pseudovaginata and $F$. tomanii belonged to the ELONGATE SINUATE morphotype. This finding supports the results of the inflorescence data analysis of these species and confirm the usefulness of the quantitative phytoliths analysis for revealing a new taxonomic character to distinguish different species of a grass genus [77]. As all the three taxa had trichomes in the adaxial surfaces of their leaves, we could not find considerable differences among the species concerning the number of the trichomes in the phytolith assemblages.

However, it was a reliable parameter in their identification key that the abaxial surfaces of the F. tomanii leaves bore trichomes, which may be the reason for the silvery epidermis. It is not clear why the silicified long epidermal cells observed under a stereo microscope were not represented in the phytolith assemblages of $F$. tomanii in larger numbers. On the other hand, the EDX measurements proved the high silica content of the abaxial epidermis of $F$. tomanii leaves, with more than triple $\mathrm{Si}$ atom $\%$ value.

Based on the length of the spikelet, the size of $F$. tomanii, the individuals in the middle of the Kiskunság were smaller, probably due to the adaptation to the drier and warmer habitat $[80,81]$ Another strategy to adapt to it is the more intensive silica accumulation [82-85], which is also a characteristic feature of $F$. tomanii. As this taxon has special morphological and anatomical characters according to its distinct area and habitat.

Based on our results, we confirmed the appearance of $F$. vaginata in natural grasslands and discovered new occurrences of F. pseudovaginata and F. tomanii. F. pseudovaginata inhabits only the Pannon region; we found endemic and natural stands of it, but in its secondary habitats it was confirmed as a completely new species. Furthermore, taxa of disturbed vegetations are currently being examined. These habitats are potential hotspots of speciation.

On bare soil surfaces of areas exposed to anthropogenous effects, two species of the genus Festuca became dominant.

\section{Conclusions}

We examined the species pool of the sandy grasslands in the steppe, forest-steppe zone of the central region of the Carpathian Basin, with greater consideration of the dominant Festuca species. Three of them occurred in the open sandy grasslands: F. vaginata, F. pseudovaginata (the latter appeared on disturbed grasslands after deforestation) and F. tomanii as a new species in the Carpathian Basin. We compared the morphotaxonomy of these taxa, especially the characteristics which can be useful 
when distinguishing them during field work. Micromorphological examination of the epidermis and phytolith analysis were new elements. These can refine the on-the-spot identification of these taxa.

Author Contributions: Conceptualization-K.P.; Data Curation-A.C.; Investigation-A.F.F., D.S., G.P., L.K., K.V., J.P., C.L., Z.L.-S. All authors have read and agreed to the published version of the manuscript.

Funding: The work was funded by OTKA K-125423, EFOP-3.6.2-16-201700001 and TKP2020-NKA-21.

Acknowledgments: The work was supported by OTKA K-125423, TKP2020-NKA-21 and EFOP-3.6.2-16-201700001. We acknowledge the general support of the Kiskunság National Park, the Duna-Ipoly National Park, the Fertő-Hanság National Park, Budapest Waterworks, The Mayor's Office, Budapest. Author Z.L.-S. was supported by the European Union and the State of Hungary, co-financed by the European Regional Development Fund in project GINOP-2.3.2.-15-2016-00009 'ICER.'

Conflicts of Interest: The authors declare no conflict of interest.

\section{References}

1. Adler, W.; Oswald, K.; Fischer, R. Exkursionflora von Österreich; Excursion Flora of Austria: Ulmer, Austria, 1994.

2. Dostal, J. Nová Květena ČSSR [New Flora of CSSR] (Vol. 2); Academia Praha: Praha, Czech Republic, 1989.

3. Király, G. Új Magyar Füvészkönyv. Magyarország Hajtásos Növényei. Határozókulcsok; Aggteleki Nemzeti Park Igazgatóság: Tengerszem, Hungary, 2009.

4. Horánszky, A.; Jankó, B.; Vida, G. Zur Biosystematik der Festuca ovina-gruppe in Ungarn [Biosystematics of Festuca ovina-group in Hungary]. Ann. Univ. Sci. Bp. Sect. Biol. 1971, 13, 95-101.

5. Májovszký, J. Adnotationes ad species gen. Festuca florae Slovakiae additamentum I. Acta Fac. Rer. Nat. Univ. Comen. 1962, 7, 317-355.

6. Nyárády, E.I.; Nyárády, A. Studie über die Arten der Sektion Ovinae Fr. der Gattung Festuca in der RVR [Study on species of Festuca ovina group in RVR]. Revue Roum. Biol. Sér. Botan. 1964, 9, 99-172.

7. Patzke, E. Vorschlag zur Gliederung der Festuca ovina L.-Gruppe in Mitteleuropa [Recommendation for classification of the Festuca ovina L. group in Central-Europe]. Österreichische Bot. Z. 1961, 108, 505-507. [CrossRef]

8. Patzke, E. Zur Kenntnis der Sammelart Festuca ovina L. im südlichen Niedersaschen [Study on Festuca ovina L. in Lower Saxony]. Götting. Flor. Rundbr. 1968, 4, 14-17.

9. Pils, G. Systematik, Karyologie und Verbreitung der Festuca uaJesiaca-Gruppe (Poaceae) in Österreich und Südtirol. Syst. Karyology Distrib. Festuca Val. Group Austria South Tyrol 1984, 24, 35-77.

10. Săvulescu, T. Flora Republicii Socialiste România; Editura Academiei Republicii Socialiste România: București, Romania, 1972.

11. Schwarzová, T. Beitrag zur Lösung taxonomischer Probleme der Festuca vaginata W. et K. und F. psammophila Hack. Acta Fac. Rer. Nat. Univ. Comen. Bot. 1967, 14, 381-414.

12. Soó, R. Festuca Studien. Acta Bot. Acad. Sci. Hung. 1955, 2, 187-221.

13. Soó, R. Zeitgemässe Taxonomie der Festuca ovina-gruppe [Recent taxonomy of Festuca ovina-group]. Acta Bot. Sci. Hung. 1973, 18, 363-377.

14. Soó, R. A Magyar Flóra és Vegetáció Rendszertani-Növényföldrajzi Kézikönyve. II [Taxonomical and Phytogeographical Manual of the Hungarian Flora and Vegetation]; Akadémiai Kiadó: Budapest, Hungary, 1973.

15. Hackel, E. Monographia Festucarum europaearum. Auctore, Eduardo Hackel. In Monographia Festucarum europaearum. Auctore, Eduardo Hackel.; Smithsonian Institution: Washington, DC, USA, 1882.

16. Isobe, S.N. Sustainable use of genetic diversity in forage and turf breeding. Ann. Bot. 2013, 111, 41-45. [CrossRef]

17. Bednarska, I.; Kostikov, I.; Tarieiev, A.; Stukonis, V. Morphological, Karyological and Molecular Characteristics of Festuca arietina Klok.-A Neglected Psammophilous Species of the Festuca valesiaca agg. from Eastern Europe. Acta Biol. Crac. Bot. 2017, 59, 35-53. [CrossRef]

18. Galli, Z.; Penksza, K.; Kiss, E.; Bucherna, N.; Heszky, L. Festuca fajok molekuláris taxonómiai vizsgálata a F. ovina csoport RAPD és AP-PCR analízise [Molecular taxonomic analysis of Festuca species: RAPD and AP-PCR analysis of the F-ovina group]. Növénytermelés 2001, 50, 375-384.

19. Galli, Z.; Penksza, K.; Kiss, E.; Sági, L.; Heszky, L.E. Low variability of internal transcribed spacer rDNA and trnL (UAA) intron sequences of several taxa in the Festuca ovina aggregate (Poaceae). Acta Biol. Hung. 2006, 57, 57-69. [CrossRef] [PubMed] 
20. Gaut, B.S.; Tredway, L.P.; Kubík, C.; Gaut, R.L.; Meyer, W. Phylogenetic relationships and genetic diversity among members of the Festuca-Lolium complex (Poaceae) based on ITS sequence data. Plant Syst. Evol. 2000, 224, 33-53. [CrossRef]

21. Loureiro, J.; Kopecký, D.; Castro, S.; Santos, C.; Silveira, P. Flow cytometric and cytogenetic analyses of Iberian Peninsula Festuca spp. Plant Syst. Evol. 2007, 269, 89-105. [CrossRef]

22. Šmarda, P. DNA ploidy levels and intraspecific DNA content variability in Romanian fescues (Festuca, Poaceae) measured in fresh and herbarium material. Folia Geobot. Phytotaxon. 2006, 41, 417-432. [CrossRef]

23. Šmarda, P. DNA ploidy level variability of some fescues (Festuca subg. Festuca, Poaceae) from Central and Southern Europe measured in fresh plants and herbarium specimens. Biology 2008, 63, 349-367. [CrossRef]

24. Šmarda, P.; Kočí, K. Chromosome number variability in central european members of the Festuca ovina and F. pallens groups (sect. Festuca). Folia Geobot. Phytotaxon. 2003, 38, 65-95. [CrossRef]

25. Šmarda, P.; Šmerda, J.; Knoll, A.; Bureš, P.; Danihelka, J. Revision of Central European taxa of Festuca ser. Psammophilae Pawlus: Morphometrical, karyological and AFLP analysis. Plant Syst. Evol. 2007, 266, 197-232. [CrossRef]

26. Šmarda, P.; Bureš, P.; Horová, L.; Foggi, B.; Rossi, G. Genome Size and GC Content Evolution of Festuca: Ancestral Expansion and Subsequent Reduction. Ann. Bot. 2008, 101, 421-433. [CrossRef]

27. Stukonis, V.; Armonienè, R.; Lemežienè, N.; Kemešytè, V.; Statkevičiūtè, G. Identification of fine-leaved species of genus Festuca by molecular methods. Pak. J. Bot. 2015, 47, 1137-1142.

28. Pawlus, M. Systematyka i rozmieszczenie gatunków grupy Festuca ovina L. w. Polsce [Classification and distribution of Festuca ovina L. in Poland]. Fragm. Florist. Geobot. 1985, 29, 219-295.

29. Borhidi, A.; Kevey, B.; Lendvai, G.; Seregélyes, T. Plant Communities of Hungary; Akadémiai Kiadó: Budapest, Hungary, 2012.

30. Krajina, V. Adnotationes ad species generis Festuca in Flora Cechoslovenika exsiccata. Acta Bot. Bohem. 1930, 9, 186-220.

31. Soó, R.; Jávorka, S. A magyar növényvilág kézikönyve. In Handbook of Hungarian Flora; Akadémiai Kiadó: Budapest, Hungary, 1951.

32. The Plant List. Available online: www.theplantlist.org (accessed on 8 September 2020).

33. Penksza, K.; Szabó, G.; Zimmermann, Z.; Lisztes-Szabó, Z.; Pápay, G.; Járdi, I.; Fúrész, A.; S-Falusi, E. A Festuca vaginata alakkör taxonómiai problematikája és ennek cönoszisztematikai vonatkozásai [The taxonomic problems of the Festuca vaginata agg. and their coenosystematic aspects]. Georg. Agric. 2019, 23, 63-76.

34. Penksza, K. Kiegészítések a hazai Festuca taxonok ismeretéhez I.: A Festuca psammophila series Festuca vaginata alakköre. Bot. Közlemények 2019, 106, 65-70. [CrossRef]

35. Wilkinson, M.J. Stace, The taxonomic relationship and typification of Festuca brevipila Tracey and Festuca lemanii Bastard (Poaceae). Watsonia 1989, 17, 289-299.

36. Budak, H.; Shearman, R.; Gaussoin, R.; Dweikat, I. Application of Sequence-related Amplified Polymorphism Markers for Characterization of Turfgrass Species. HortScience 2004, 39, 955-958. [CrossRef]

37. Lonati, M.; Lonati, S. Le praterie xerofile a Festuca trachyphylla (Hackel) Krajina della bassa Valsesia (Piemonte, Italia) [The xerophilous Festuca trachyphylla (Hackel) Krajina grasslands in the lower Valsesia (Piedmont, Italy)]. Fitosociologia 2007, 44, 109-118.

38. Stukonis, V.; Lemežienè, N.; Kanapeckas, J. Suitability of narow-leaved Festuca species for turf. Agron. Res. 2010, 8, 729-734.

39. Dąbrowska, A. Morpho-anatomical structure of the leaves of Festuca trahyphylla (Hack.) Krajina in the ecological aspect. Mod. Phytomorphol. 2012, 1, 19-22. [CrossRef]

40. Gugnacka-Fiedor, W.; Adamska, E. The preservation state of the flora and vegetation of the artillery range near the city of Torun. Ecol. Quest. 2010, 12, 75-86. [CrossRef]

41. Löbel, S.; Dengler, J. Dry grassland communities on southern Öland: Phytosociology, ecology, and diversity. Acta Phytogeogr. Suec. 2008, 88, 13-31. [CrossRef]

42. Rūsinna, S. Nelku aira Aira Caryophyllea L. Latvija [Aira caryophyllea L. in Latvia]. Latv. Veǵetācija 2003, 7, 33-43.

43. Kaczmarek, Z.; Gajewski, P.; Mocek, A.; Grzelak, M.; Knioła, A.; Glina, B. Geobotanical conditions of ecological grasslands on light river alluvial soils. J. Res. Appl. Agric. Eng. 2015, 60, 131-135.

44. Böhnert, W.; Reichhoff, L. Die Pflanzengesellschaften des Naturschutzgebietes "Steckby-Lödderitzer Forst". Plant Communities Steckby-Lödderitzer Forst Nat. Reserve 1978, 15, 106-114. 
45. Fischer, W.; Kummer, V.; Pötsch, J. Zur Vegetation des Feuchtgebietes Internationaler Bedeutung (FIB) untere Havel [Vegetation of lower Havel, an internationally important wetland area]. Nat. Landsch. Brandenbg. 1995, 4, 12-18.

46. Nienartowicz, A.; Kaminski, D.; Kunz, M.; Deptuła, M.; Adamska, E. Changes in the plant cover of the dune hill in Folusz near Szubin (NW Poland) between 1959 and 2012: The problem of preservation of xerothermic grasslands in the agricultural landscape. Ecol. Quest. 2015, 20, 23. [CrossRef]

47. Kovář, P. Contribution to the syntaxonomy of the Festuca trachyphylla-grass-lands. Preslia 1980, 52, $217-226$.

48. Di Pietro, R. New Dry Grassland Associations from the Ausoni-Aurunci Mountains (Central Italy)Syntaxonomical Updating and Discussion on the Higher Rank Syntaxa. Hacquetia 2011, 10, 183-231. [CrossRef]

49. Stace, C.A.; Al-Bermani, A.-K.K.A.; Wilkinson, M.J. The distinction between the Festuca ovina L. and Festuca rubra L. aggregates in the British Isles. Watsonia 1992, 19, 107-112.

50. Blackman, E. Opaline silica bodies in the range grasses of southern Alberta. Can. J. Bot. 1971, 49, $769-781$. [CrossRef]

51. Brown, W.V. Leaf Anatomy in Grass Systematics. Int. J. Plant Sci. 1958, 119, 170-178. [CrossRef]

52. Metcalfe, C.R. Anatomy of the Monocotyledons: I. Gramineae; Clarendon Press: Oxford, UK, 1960.

53. Palmer, P.G.; Tucker, A.E. A Scanning Electron Microscope Survey of the Epidermis of East African Grasses, I. Smithson. Contrib. Bot. 1981, 49, 1-84. [CrossRef]

54. Tateoka, T.; Inoue, S.; Kawano, S. Notes on Some Grasses. IX. Systematic Significance of Bicellular Microhairs of Leaf Epidermis. Int. J. Plant Sci. 1959, 121, 80-91. [CrossRef]

55. Brown, D.A. Prospects and limits of a phytolith key for grasses in the central United States. J. Archaeol. Sci. 1984, 11, 345-368. [CrossRef]

56. Fredlund, G.G.; Tieszen, L.T. Modern Phytolith Assemblages from the North American Great Plains. J. Biogeogr. 1994, 21, 321. [CrossRef]

57. Krishnan, S.; Samson, N.P.; Ravichandran, P.; Narasimhan, D.; Dayanandan, P. Phytoliths of Indian grasses and their potential use in identification. Bot. J. Linn. Soc. 2000, 132, 241-252. [CrossRef]

58. Lu, H.; Liu, K.-B. Morphological variations of lobate phytoliths from grasses in China and the south-eastern United States. Divers. Distrib. 2002, 9,73-87. [CrossRef]

59. Mulholland, S.C. Phytolith shape frequencies in North Dakota grasses: A comparison to general patterns. J. Archaeol. Sci. 1989, 16, 489-511. [CrossRef]

60. Mulholland, S.C.; Rapp, G. A Morphological Classification of Grass Silica-Bodies. In Phytolith Systematics; Springer Science and Business Media LLC: Berlin, Germany, 1992; pp. 65-89.

61. Prychid, C.J.; Rudall, P.J.; Gregory, M. Systematics and Biology of Silica Bodies in Monocotyledons. Bot. Rev. 2003, 69, 377-440. [CrossRef]

62. Twiss, P.C.; Suess, E.; Smith, R.M. Morphological Classification of Grass Phytoliths. Soil Sci. Soc. Am. J. 1969, 33, 109-115. [CrossRef]

63. Pepi, M.F.; Zucol, A.F.; Arriaga, M. Comparative phytolith analysis of Festuca (Pooideae: Poaceae) species native to Tierra del Fuego, Argentina. Botany 2012, 90, 1113-1124. [CrossRef]

64. Ortúñez, E.; De La Fuente, V. Epidermal micromorphology of the genus Festuca L. (Poaceae) in the Iberian Peninsula. Plant Syst. Evol. 2010, 284, 201-218. [CrossRef]

65. Zarinkamar, F.; Jouyandeh, N.E. Foliar anatomy and micromorphology of Festuca L. and its taxonomic applications. Taxon. Biosyst. 2011, 8, 55-63.

66. Korneck, D.; Gregor, T. Festuca tomanii sp. nov., ein Dünen-Schwingel des nördlichen oberrhein-, des mittleren main- und des böhmischen Elbetales. Kochia 2015, 9, 37-58.

67. Bajor, Z. Effect of conservation management practices on sand grassland vegetation in budapest, hungary. Appl. Ecol. Environ. Res. 2016, 14, 233-247. [CrossRef]

68. Csány-Kovács, C.; Horánszky, A. Charakterisierung der Festuca-Populationen aufgrund der Merkmale der Rispe. Ann. Univ. Sci. Bp. Rolando Eötvös Nomin. Sect. Biol. 1973, 15, 59-74.

69. Hammer, O.; Harper, D.; Ryan, P. PAST: Paleontological Statistics Software Package for Education and Data Analysis. Palaeontol. Electron. 2001, 4, 1-9.

70. Harper, D.A.T. Numerical Palaeobiology: Computer-Based Modelling and Analysis of Fossils and Their Distributions; John Wiley \& Sons: Hoboken, NJ, USA, 1999. 
71. Weiner, S.; Albert, R. Study of Phytoliths in Prehistoric Ash Layers from Kebara and Tabun Caves Using a Quantitative Approach. In Phytoliths-Applications in Earth Science and Human History; Informa UK Limited: Colchester, UK, 2001; pp. 251-266.

72. Mercader, J.; Bennett, T.; Esselmont, C.; Simpson, S.; Walde, D. Phytoliths in woody plants from the Miombo woodlands of Mozambique. Ann. Bot. 2009, 104, 91-113. [CrossRef]

73. Mercader, J.; Astudillo, F.; Barkworth, M.; Bennett, T.; Esselmont, C.; Kinyanjui, R.; Grossman, D.L.; Simpson, S.; Walde, D. Poaceae phytoliths from the Niassa Rift, Mozambique. J. Archaeol. Sci. 2010, 37, 1953-1967. [CrossRef]

74. Neumann, K.; Strömberg, C.A.E.; Ball, T.; Albert, R.M.; Vrydaghs, L.; Cummings, L.S.; International Committee for Phytolith Taxonomy (ICPT). International Code for Phytolith Nomenclature (ICPN) 2.0. Ann. Bot. 2019, 124, 189-199. [CrossRef]

75. Galbraith, D.W.; Harkins, K.R.; Maddox, J.M.; Ayres, N.M.; Sharma, D.P.; Firoozabady, E. Rapid flow cytometric analysis of the cell cycle in intact plant tissues. Science 1983, 220, 1049-1051. [CrossRef]

76. Penksza, K. Festuca pseudovaginata, a new species from sandy areas of the Carpathian Basin. Acta Bot. Hung. 2003, 45, 365-372. [CrossRef]

77. Lisztes-Szabó, Z.; Kovács, S.; Balogh, P.; Daróczi, L.; Penksza, K.; Pető, Á. Quantifiable differences between phytolith assemblages detected at species level: Analysis of the leaves of nine Poa species (Poaceae). Acta Soc. Bot. Pol. 2015, 84, 369-383. [CrossRef]

78. Horánszky, A. Festuca-tanulmányok I. [Festuca-studies I.]. Bot. Közlemények 1969, 56, 149-154.

79. Horánszky, A. Festuca-tanulmányok II. [Festuca-studies II.]. Bot. Közlemények 1970, 57, 207-215.

80. Ladányi, Z.; Rakonczai, J.; Kovács, F.; Geiger, J.; Deák, J.Á. The effect of recent climatic change on the Great Hungarian Plain. Cereal Res. Commun. 2009, 37, 477-480.

81. Ladányi, Z.; Rakonczai, J.; Van Leeuwen, B. Evaluation of precipitation-vegetation interaction on a climate-sensitive landscape using vegetation indices. J. Appl. Remote Sens. 2011, 5, 53519. [CrossRef]

82. Jones, L.H.P.; Handreck, K.A. Studies of silica in the oat plant. Plant Soil 1965, 23, 79-96. [CrossRef]

83. Madella, M.; Jones, M.; Echlin, P.; Powers-Jones, A.; Moore, M. Plant water availability and analytical microscopy of phytoliths: Implications for ancient irrigation in arid zones. Quat. Int. 2009, 193, 32-40. [CrossRef]

84. Raven, J.A. The transport and function of silicon in plants. Biol. Rev. 1983, 58, 179-207. [CrossRef]

85. Sangster, A.G.; Parry, D.W. Silica Deposition in the Grass Leaf in Relation to Transpiration and the Effect of Dinitrophenol. Ann. Bot. 1971, 35, 667-677. [CrossRef]

Publisher's Note: MDPI stays neutral with regard to jurisdictional claims in published maps and institutional affiliations.

(C) 2020 by the authors. Licensee MDPI, Basel, Switzerland. This article is an open access article distributed under the terms and conditions of the Creative Commons Attribution (CC BY) license (http://creativecommons.org/licenses/by/4.0/). 